\title{
Mystery fraud accusations
}

\author{
Stem-cell researchers targeted by e-mails from unidentified group.
}

\section{BY HEIDI LEDFORD}

$\mathrm{I}$ t's a researcher's worst nightmare: an unexpected allegation of scientific misconduct 1 broadcast to colleagues and journalists without any clue as to where the accusation is coming from or how to respond to it. That's what happened twice last week, when a group calling itself 'Stem Cell Watch' sent e-mails claiming evidence of fraud in recent publications from prominent stem-cell researchers. "We are continuing to point out suspicious results and duplications reported by scientists in the stem-cell field," the group wrote.

There is no indication that any of its accusations are correct, but the group has rattled a rapidly moving field that is accustomed to controversy, causing researchers to fear for their credibility and forcing journal editors to re-examine published work. (The International Cellular Medicine Society also runs a website called Stem Cell Watch, which has no association with the e-mail group.)

At least three research teams have found themselves in the cross hairs of Stem Cell Watch, and the group says it is considering action against others. But its behaviour is raising the hackles of scientists, who believe the alerts are smearing reputations without cause. "I find this kind of activity unhelpful and defamatory," says Doug Melton, co-director of the Harvard Stem Cell Institute in Cambridge, Massachusetts.

Critics argue that Stem Cell Watch is not following scientific etiquette, which says that concerns should be addressed directly and openly to the authors of a paper. Melton says he received a message, addressed only to him, from the group earlier this year. The e-mail accused another stem-cell researcher of misconduct, but because it was anonymous, Melton simply deleted it.

Stem Cell Watch provides little information about its members. They claim to be students majoring in biology who discuss papers taught in class. Their aim, they say, is to alert professionals to problems they find in the literature, to ensure that they are handled seriously.

One of Stem Cell Watch's missives last week stated that images of the same cells had been used more than once, but with different coloration, in a 2009 paper in the Proceedings of the National Academy of Sciences (S. Friling

$\rightarrow$ NATURE.COM

Comment on this article online at: go.nature.com/qxuolr
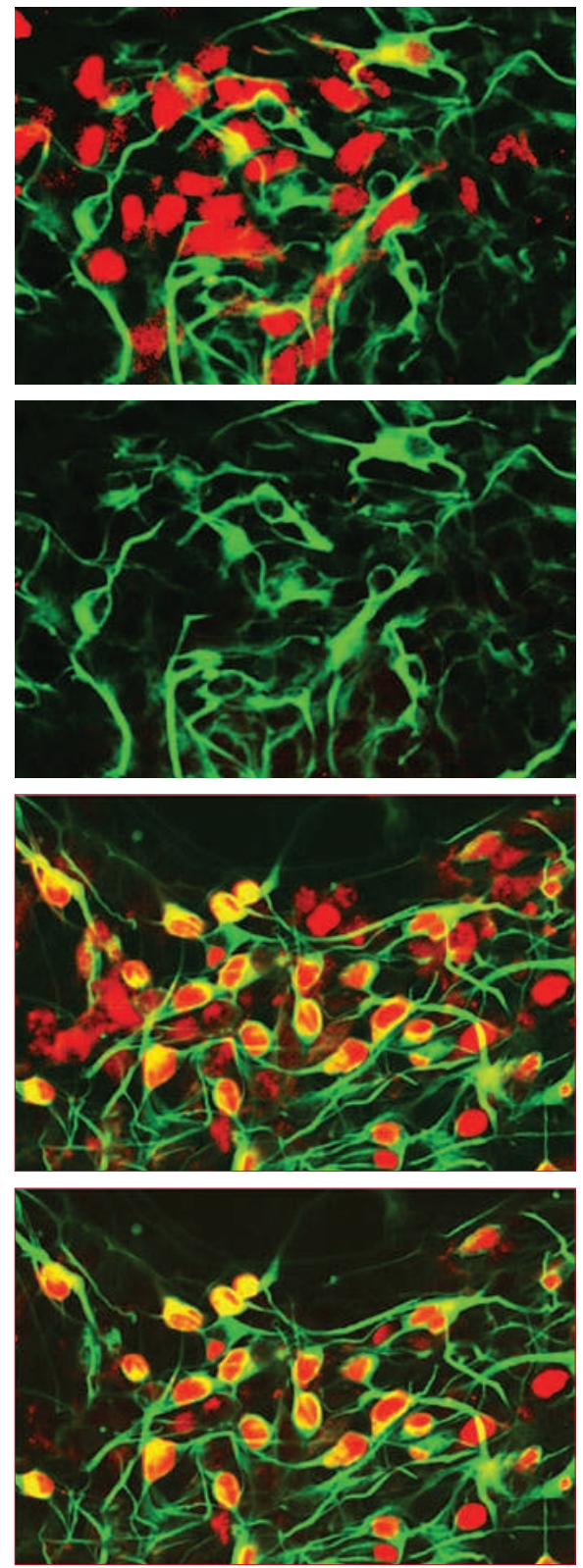

Anonymous tipsters forced researchers to defend the use of the same cells in multiple images.

Johan Ericson and Thomas Perlmann at the Karolinska Institute in Sweden, but the images were appropriate because multiple proteins in the cells had been labelled with differently coloured fluorescent tags. "We appreciate any opportunity to respond to critique or concerns raised about our work," Perlmann and Ericson said in a written statement. "However, we regret that these serious accusations were made anonymously, as we strongly believe in the concept of an open and transparent $\stackrel{8}{\circ}$ communication about suspected errors in published data." A spokeswoman at the Proceedings of the National Academy of Sciences says that the journal is obliged to investigate the group's claims as a matter of policy.

In another e-mail, Stem Cell Watch attacked a 2009 paper in Nature in which Konrad Hochedlinger at the Harvard Stem Cell Institute and his colleagues reported a new link between the generation of induced pluripotent cells and cancer $\stackrel{\sim}{\omega}$ (J. Utikal et al. Nature 460, 1145-1148; 2009). The group says it decided to take action after "several conceptual flaws" led them to evaluate the paper's images more closely. Their e-mail states that the images in one figure "appear weird", and that the same embryo is probably depicted in the figure's control and experimental panels. The anonymous accusers also asserted that the fluorescence staining in the experimental panel "appears very artificial to the experienced eye" and may have been "introduced by fraudulent computer photo manipulation or other means". The message concluded with a call for Nature to investigate the matter.

"We wouldn't encourage anonymous accusations, least of all those broadcast indiscriminately," says Philip Campbell, Nature's editor-in-chief. "But there have been occasions where anonymous whistle-blowing has revealed fraudulent papers, so we will at least consider such accusations."

Hochedlinger was caught by surprise by the nature of the accusation. "I have never received e-mails like this before and, to be honest, I find it quite upsetting," he says. He has reviewed the original images and says the allegations are entirely unfounded. He has submitted the originals to Nature to assist with any review.

As before, the accusations seem unlikely to be valid. The Nature paper was one of several published simultaneously by different research groups reporting similar results. Although Nature has not commented on the specific allegations, five stem-cell researchers contacted by a Nature reporter say they saw no evidence of fraud in either the original images or the figure as presented in publication. Whoever the group is, says Robin Lovell-Badge at the National Institute for Medical Research in London, "it seems they do not have that much experience looking at mouse embryos".

Lovell-Badge adds that he finds the incident worrying. "Although we don't want fraudulent work to be published," he says, "this group does not seem to have the skill or knowledge to make a fair assessment." - 


\section{Mountaintop mining plans close to defeat}

\section{Environmental review details 'unacceptable' impacts.}

\section{BY NATASHA GILBERT}

$\mathrm{T}$ The rising tide of scientific evidence and public protest - against mountaintop mining looks set to claim its first major victory. By the end of this year, the US Environmental Protection Agency (EPA) is expected to revoke a permit allowing mining company Arch Coal to extract coal from the Appalachian Mountains in West Virginia. This would be the first time a permit for the controversial mining practice, long suspected of causing environmental damage, has been vetoed by the agency.

A scientific review (see go.nature.com/ hsuhrt) carried out by the EPA and published on 15 October concluded that the project, Spruce 1, would have "unacceptable" effects on water quality and wildlife, and recommended its permit be revoked. Carol Raulston,

a spokeswoman for the National Mining Association (NMA), based in Washington DC, told Nature: "The NMA has no reason to believe the EPA will not follow the recommendations in its final determination on the Spruce permit."

The move is likely to set the tone for decisions on other mining projects. More than 100 surface-mining permits are pending approval with the Army Corps of Engineers, which is responsible for investigating, developing and maintaining the nation's water and related environmental resources. The corps issued approval for the Spruce 1 project in 2007 to Mingo Logan, a subsidiary of Arch Coal. But

DNATURE.COM

For more on mountaintop mining see: go.nature.com/9qlirbu the EPA can revoke a permit if it feels that environmental concerns have not been fully addressed.

"If the EPA proceeds with its unlawful veto of the Spruce permit, as it appears determined to do, every business in the nation would be put on notice that any lawfully issued permit can be revoked at any time according to the whims of the federal government," says Kim Link, a spokeswoman for Arch Coal.

Mountaintop mining exposes seams of coal near mountain peaks by stripping away forests and breaking up rock with explosives. The debris is often dumped in the valleys below. The EPA review says that Spruce 1 would increase the electrical conductivity of stream water (a measure of its ionic concentration) to unacceptably high levels, harming aquatic wildlife.

The NMA says that the EPA's use of electrical conductivity as a proxy for water pollution is "faulty science". "Conductivity is but one metric of water quality and is not recognized by hydrologists as satisfactory when used as the chief or only metric," says Luke Popovich, a spokesman for the NMA. However, research has shown a strong correlation between increased levels of conductivity and harm to aquatic macro-invertebrates (see Nature 466, 806; 2010).

Arch Coal had already filed a lawsuit in April challenging the EPA's authority to veto permits. The company now plans to submit a rebuttal to the review by 5 November. 